УДК 34

DOI https: / / doi.org/10.32837/yuv.v0i6.2073

\title{
М. Горішня,
}

здобувач кафедри адміністративного та митного права

Університету митної справи та фінансів

\section{ГЕНЕЗА НОРМАТИВНОГО РЕГУЛЮВАННЯ ПРАВОВІДНОСИН В АРХІВНІЙ СФЕРІ}

Актуальність проблеми. Кожен новий етап розвитку суспільства потребує перегляду та вдосконалення нормативної бази, яка повинна відповідати інноваційним викликам поточного часу. Стосується це всіх сфер життєдіяльності і навіть такого комплексу, як система архівної справи, яка виступає, як багатьом здається, тільки ретранслятором історичного минулого. Архіви мають велике значення в забезпечені історичної наступності. Саме вони фіксують еволюцію суспільних процесів та гарантують передачу соціальних, культурних та історичних цінностей від покоління до покоління.

Фрагментарно дослідження проблеми правового регулювання організації та функціонування архівної справи проводили В. Автократов, Е. Алексєєва, О.Ардашкіна, А. Артізов, I. Асфандіярова, В. Бароне, Г. Боряк, Є. Буров, Х. Вальберг, М. Васильченко, М. Вилегжаніна, Х. Вінтонів, С. Горохов, Л. Драгомірова, С. Дроков, А. Єлпатьєвський, Т. Ємельянова, I. Захарова, Г. Калімулліна, В. Козлов, I. Косов, В. Кривенко, А. Курцер, М. Лапіна, Л. Левченко, Л. Лішин, Є. Лобанов, В. Магідов, Р. Мельник, О. Медушевський, Т. Хорхордіна, О. Леонтьєва, К. Новохатський, В. Носевич, Г. Осічкина, М. Палієнко, Г. Петерсон, О. Рисков, П. Стоян, В. Тихонов, А. Токарська, О. Харченко, А. Черешня, Г. Швецова-Водка, А. Шелест, О. Шерман, Т. Ширко. Монографічна література юридичного спрямування в національ- ному науковому полі з цього питання практично відсутня.

Незважаючи на досить велику кількість наявних праць, тема правового регулювання архівної діяльності залишається недостатньо дослідженою.

Предмет публікації - витоки становлення нормативно-правових основ організації архівної діяльності та еволюція архівного законодавства.

Метою статті $€$ ретроспективне означення правових аспектів нормативного регулювання організаціі та функціонування архівної діяльності з деталізацією ранніх етапів.

\section{Методологічною основою} $€$ застосування міждисциплінарного підходу, що базується на комплексі загальнонаукових та спеціальних методів, зумовлених метою і завданнями дослідження, принципах об'єктивності, системності, міждисциплінарності. Використовувався аналіз сучасної наукової та історичної літератури з досліджуваної проблематики, а також такі методи, як індуктивний та дедуктивний, генетичний, спостереження, порівняльний, а також висновок за аналогією. Генетичний метод застосовувався не тільки в дослідженні історії архівів та архівістики, але й у процесі впорядкування фондів методом відновлення давніх укладів. Ретроспективний метод дав змогу відштовхнутися від сучасних проблем, заглибитися в архівну давнину, визначити найбільш типові риси та правові особливості кожного етапу архівного будівництва відповідно до сукупного розвитку юридичної та архівознавчої думки. 
Власне, поняття «архівне право» з'явилося ще в середні століття і розумілося як право землевласника. Саме певна сукупність документів, отриманих від влади сюзерена, імператора або короля, давала можливість володарю землі представляти виписки з них або паперові оригінали для вирішення суперечок, які виникали в системі ленного землеволодіння.

Згодом таке право з'явилося у церкви. Потім представники окремих міст почали отримувати від Папи Римського або Імператора спеціальні привілеї щодо наявних можливостей стосовно зберігання документів, а за виникнення спірних питань посилатися на ці папери як на невід'ємне право.

Надалі поняття архівного права сильно видозмінилося.

Перші відомості про архіви сходять ще з часів виникнення найдавніших рабовласницьких держав Сходу та Європи, адже найбільшим виробником і власником документальних матеріалів в усі часи була держава, під час діяльності якої складалися та накопичувалися великі архіви. На їхню організацію безпосередньо впливали зміни в організації та функціонуванні державного апарату, тому розвиток архівної справи тісно пов'язаний з історією державних установ. Передумовами виникнення архівів була поява писемності, формування складних форм господарської організації, закладання законодавчої і розпорядчої діяльності держави, міжнародних відносин тощо. Все це викликало необхідність застосування письмових документів і діловодства.

Організація архівів, їх склад i зміст, способи зберігання та види оброблення документальних матеріалів змінювалися відповідно до перетворень у соціально-економічних відносинах, 3 розвитком державності та культури. Кожному історичному типу суспільства, кожній суспільно-економічної формації на певних етапах ii розвитку відповідають характерні типи архівів [3, с. 4].
Перш ніж архіви почали служити історії, вони використовувалися для доказу прав громадян і забезпечували діяльність державних інститутів. Цей зв'язок сприймався настільки природньо, що в деякі періоди розвитку людства навіть дозволялося вважати, що зберігання документа в архіві вже $є$ доказом його справжності.

Відомості про перші архіви Київської Русі належать до X ст., коли архівна система ще не була централізованою. Архіви існували автономно при монастирях і церквах, пізніше при школах і в бібліотеках. Спорадично з'являлися внутрішні статути тих чи інших архівів.

Становлення централізованої держави супроводжувалося впровадженням наказного діловодства. 3 кінця XV ст. виникають накази, які поєднують централізоване, функціонально-територіальне, незалежне від феодальної підпорядкованості управління. 3 цих часів вже існує сенс говорити про появу служивих людей чиновників, для яких документ став невід'ємним інструментом професійної діяльності. Першим офіційним документом, у якому згадувалося зберігання справ, можна вважати царський Судебник (1550р.), що зобов’язував «дбайливо зберігати» всі справи державних установ. У XVI - XVII ст. ст. у наказах відклалися великі комплекси архівних матеріалів, але в цей період часу всі офіційні папери ще були складовою частиною поточного діловодства.

Характерною особливістю наказного діловодства було те, що воно багато в чому спиралося на сукупність традицій, звичаїв, переказів, ритуалів, які передавалися з покоління в покоління. Згодом вони були санкціоновані державою, тому стали нормою звичаєвого права. У 1680 р. був виданий Указ московського царя, який вимагав провести опис усіх офіційних справ. Саме в ньому вперше встановлювалися норми оформлення й вироблялася технологія проходження доку- 
ментації в органах управління, а також складався певний порядок зберігання різних видів документів. Наказне діловодство відіграло важливу роль у період становлення та зміцнення централізованого управління, однак на наступному етапі розвитку держави воно значно змінилося [7, с. 3-8].

Важливо зазначити, що наявність архіву ще не означає появу архівної справи. Для створення такого напряму діяльності необхідно, щоб виконувалось щонайменше три умови, такі як наявність системи архівів, визначення складу документів, які в них зберігаються, та встановлення певного порядку їх комплектування. Першим законодавчим актом, який визначив основні принципи реєстрації, класифікації та опису документів, став Генеральний регламент (1720р.), який затвердив Петро І. Цим актом було введено саме поняття «архів», виділено його у вигляді окремого підрозділу колегії, що дало змогу провести чітку межу між архівними матеріалами й документами поточного діловодства. Було виділено три категорії архівів, такі як поточні, які створювались при канцеляріях; відомчі (архіви колегій); державні (при колегії закордонних справ і ревізійної служби колегіi). Генеральний регламент став фактично першим законом українських земель, який регулював питання роботи з документами в центральних державних установах. Саме цим актом встановлювалися порядок документування роботи колегій, правила використання печаток, вводилися елементи збереження державної таємниці.

Генеральним регламентом було вперше визначено порядок здачі закінчених провадженням справ. Архівному зберіганню документів була присвячена спеціальна глава Регламенту (XLIV), у якій також передбачалося створення єдиної системи архівів. В канцеляріях і конторах виникали поточні архіви, а службовці, які ними завідували, стали називатися архіва- ріусами. В цих документосховищах повинні були зберігатися офіційні папери протягом трьох років. Після закінчення цього терміну офіційні папери, крім тих, які залишалися в канцеляріях для довідок, обов'язково здавалися до архіву колегії. Саме Генеральний регламент нормативно відділив архіви від канцелярій і вперше у світовій практиці наказав державним установам здавати всі відпрацьовані документи в архіви після спливання трьох років [6, с. 103-110].

Таким чином, Генеральний регламент законодавчо закріпив порядок роботи 3 документами 3 моменту ї створення до архівного зберігання.

Втім, на практиці не було створено головного архіву, який би координував і регламентував роботу всіх документосховищ. Це призвело до появи безлічі не пов'язаних між собою архівів. В першої чверті XVIII ст. була проведена реформа державного апарату управління. Завдяки цьому було встановлено одноманітну систему організаційного устрою та діловодства державних установ на основі бюрократичного централізму.

Однак, незважаючи на недосконалість архівної системи, завдяки проведеній реформі органів державної влади відбулося часткове укрупнення архівів. Так, на основі декількох десятків канцелярських управлінь було сформовано 12 колегій. Це привело до розмежування функціональних повноважень первинних архівних закладів і сприяло формуванню однорідних фондів в одній і тій же архівній установі.

Загалом протягом XVIII ст. було видано багато правових актів, що стосувалися архівної справи. Серед них можна виділити декілька указів, один 3 яких вимагає містити справи «в збереженому місці» (1726р.); інший наказує будувати для архівів кам'яні будівлі із залізними затворами і гратами на вікнах, «від дерев'яної будови не в близькості» (1736р.); третій забороняє виносити справи за межі 
архівів (1763р.); четвертий зобов'язує всі установи здавати документи в архів в упорядкованому стані в супроводі реєстрів (1781 р.) [4, с. 19].

Указ Сенату від 1736 р. вимагав не тільки будувати для архівів кам'яні будівлі із залізними затворами і гратами на вікнах, але й розташовувати їх подалі від дерев'яних споруд, щоб виключити небезпеку виникнення пожежі. Катерина II провела губернську реформу, на меті якої було проведення реорганізації бюрократичного апарату управління на місцях.

Втім, сформований порядок діловодства принципово не змінився. Закон «Установи для управління губерній» (1775 р.) законодавчо закріпив наявну ієрархію державних установ і порядок зберігання документаціі.

У XVIII - XIX ст. ст. була створена ціла низка архівів, де зберігалися важливі історичні документи. Влада при цьому намагалася зосередити в нечисленних сховищах найбільш важливі в політичному й економічному сенсі матеріали. В кінці XVIII - XIX ст. ст. почали з'являтися перші відомчі архіви на місцях, а саме виникла ціла мережа архівів адміністративних та судових установ у провінціях, містах і повітах.

У другій половині XIX ст. почали створюватися губернські наукові комісії 3 архівної справи. Однак робота вчених, які входили до складу цих комісій, не фінансувалася урядом. Вони існували за рахунок пожертвувань приватних осіб, земств, міських дум. Відсутність нормативно-законодавчої бази для зберігання архівних матеріалів та недостатне фінансування негативно позначилися на їх роботі.

Подальші реформи системи державного апарату тягли за собою зміни в системі архівних установ. Це закріплювалося відповідними нормативними актами. На початку XIX ст. знову була проведена реформа органів державного управління, в результаті якої докорінним змінам піддався центральний апарат влади. Замість колегій вводилися міністерства, що діяли на принципах єдиноначальності з безпосереднім підпорядкуванням імператору.

У 1811 р. було прийнято «Загальну установу міністерств». Цей нормативний акт регламентував структуру і всі напрями діяльності міністерств, зокрема обов'язкове створення при міністерствах і департаментах документосховищ. Саме це привело до зростання великого числа архівів, відсутності єдиного керівництва й роздрібненості фондів міністерств. Історичні архіви працювали за правилами, які складалися і затверджувалися керівниками архівів, відомчі за інструкціями відповідних відомств та установ [8, с. 143-147].

Наступний етап змін державного діловодства на українських землях настає на початку XIX ст., тобто при Олександрі І. 25 червня 1811 р. був прийнятий Закон «Загальна установа міністерств». В цьому Законі встановлювалися функції, структура та сфери діяльності міністерств. У міністерствах була створена однакова система діловодства і канцелярій, тобто структурних частин установ, де було зосереджено все письмоводство. Щодо постановки архівної справи в розглянутий період, то необхідно відзначити, що до жовтня 1917 р. Російська імперія була однією з небагатьох великих європейських держав (разом 3 Австро-Угорщиною), де архівна справа залишалася нецентралізованою. Ідея створення головного управління архівів була висунута вперше у 1820 р. бароном Розенкампфом, який підготував і представив Раді Комісії зі складання законів «План щодо приведення в кращий устрій архівів взагалі». Однак цей план не був реалізований.

У 1869 р. вчений-архівознавець M. Калачов сформулював діючі сьогодні напрями раціонально організованої роботи архівів. Він запропонував поділити архіви на приватні, 
громадські або урядові, встановити правила відбору документів для зберігання та знищення, а також класифікувати ї [5].

Ідея централізації знайшла вираження у створенні у 1873 р. Головної архівної комісії як органу центрального управління архівами. Зовсім по-іншому бачив вирішення проблем централізації архівів відомий історик і архівіст Д. Самоквасов. Він вважав за необхідне починати реформу зі створення головного архівного управління, загального для всіх установ і відомств, в чиєму розгляді перебували б усі питання цієї справи. У проєкті архівної реформи Д. Самоквасова передбачалося створення широкої мережі державних архівів.

До особливостей розвитку архівної системи у XIX ст. можна віднести виникнення та розвиток історичних архівів (архіви міністерств і відомств Російської імперіï). Так, у рамках військового міністерства було створено два історичних архіви, а саме Військово-топографічне депо (пізніше отримав назву Військово-вчений архів) і Московське відділення інспекторського департаменту (пізніше називався архів Головного штабу). Замість Державного архіву Колегіі іноземних справ у червні 1834 р. був створений Державний архів Міністерства закордонних справ.

Особливе значення для архівної справи мало створення у 1852 р. Московського архіву міністерства юстиції (МАМЮ), оскільки згодом саме цей архів став своєрідним методичним центром, що визначав роботу історичних архівів, а також архівів низки урядових установ [16, с. 9-16].

У XIX ст. деякі нормативні акти Військового та інших відомств ввели термін зберігання закінчених справ. Це було пов'язано з проблемою переповнення державних установ документами, які втратили оперативне значення. Так, Правила Військового міністерства «Про порядок зберігання та знищення вирішених справ» 1836 р. розділили всі справи залежно від термінів зберігання на три групи («розряди»). До першої групи увійшли такі справи, як канцелярське листування, заяви, відомості та інші документи, які мали знищуватися відразу після їх відпрацювання. Друга група включала справи щодо особового складу, слідчі протоколи, військово-судові акти та інші документи, які мали передаватися в архів «на стільки часу, на скільки буде в них потреба». Третя чільна група включала найбільш важливі справи, зокрема закони, положення, річні звіти. Вони мали зберігатися постійно. За зразком Військового міністерства усі інші відомства стали також поділяти всі документи на справи, які не підлягають зберіганню в архіві; справи тимчасового зберігання; справи постійного зберігання.

Циркуляр MBC «Про розбирання архівних справ установ Міністерства внутрішніх справ» від 9 грудня 1852 р. і 5 березня 1853 р. надав переліки тих справ, які не повинні підлягати знищенню [11, с. 32, 55, 58]. Це був великий реєстр справ, що включав документи 3 обліку населення (наприклад, «за свідченнями про дворянство і зі складання родоводів книг»), про власність на землю («про зміни в земляних володіннях та їхніх власників»), про будівництво, надзвичайні ситуації, врожайність, епідемії, а також секретні формуляри $[11$, с. $3,18,190]$.

У XIX ст. з'явився термін «архівне право», який було включено до тлумачних словників. Так у довіднику Ф. Брокгауза та I. Єфрона (1890р.) зазначено: «Уряд, володіючи архівних правом, для його поняття вводить: 1) ведення всіх державних урядових архівів; 2) вимогу про те, щоб громади брали участь у витратах на утримання історичних архівів; 3) вимогу про те, щоб громади мали свої архіви i вели їх належним чином» [14]. Словник Ф. Толя (1863р.) визначав архівне право як «закони і правила, що належать до архіву». Крім 
центральних, у XIX ст. приділялася увага створенню місцевих (провінційних) архівів. Так, у 1820 р. було прийнято Спільну губернську постанову, яка регламентувала створення двох архівів при кожній державній установі: один для поточного діловодства, інший - для закінчених справ [12, с. 87].

Однак фінансування цих архівів було недостатнім, у зв'язку 3 чим посилювалися проблеми 3 приміщеннями та утриманням службовців. Під час Першої світової війни багато джерел загинули через погану організацію та несвоєчасну евакуацію, що додатково ускладнило ситуацію. У більшості архівів зупинилася робота 3 упорядкування архівних документів [9, с. $158-161]$.

Таким чином, головною особливістю архівної справи Російської імперії була відсутність архівної системи в іï сучасному розумінні. Крім того, були відсутні головні архівні установи, які могли б здійснювати централізоване управління та надавати методичні рекомендації.

Генеральний регламент закріплював лише загальні принципи роботи архівів. Спеціальних нормативних документів, які нормативно регламентували організаційно-правову діяльність архівів і технологію роботи з архівними документами, ще не було прийнято. Кожен архів існував відокремленим чином один від одного i повністю підпорядковувався або урядовій установі, або відповідній організації чи підприємству. Як правило, архів входив до складу органів державного влади на правах структурного підрозділу. 3 огляду на це архіви Російської імперії нерідко розглядають як відомчі.

Зародженню архівної справи в Україні більшою мірою сприяв розвиток козацько-гетьманської держави, тому вагомою подією цієї епохи було створення першого українського державного архіву. Поступове знищення автономізації України та закладання імперських інституцій для піi управління наклали свій відбиток на формування й склад державних установ. Разом 3 уже наявними центральними та місцевими адміністраціями почали зароджуватися монастирські та родові архіви. Саме цей період слід вважати початком централізації архівної справи. Реформування адміністративного управління українськими територіями не оминуло організацію архівних фондів. Документи ліквідованих установ передавалися у розпорядження новостворених адміністративно-територіальних органів. Так, входження Закарпаття до складу Угорщини та реорганізація їі місцевих органів значним чином вплинули на стан архівної справи цієї теритоpiï. Адміністративно-територіальний поділ Закарпаття на комітати (жупи) сприяв будівництву, за рішенням угорської влади, адміністративних споруд для них. В результаті їхньої діяльності оформлювалося багато різних документів. Завдяки цьому виникла нагальна потреба створення довготривалих регіональних документосховищ. Ось так на Закарпатті з'явилися стаціонарні жупні архіви.

В установах місцевого управління відводилась окрема комірчина, куди складали комітатські службові папери. Так, поступово у цьому місці збиралося повсякденне справочинство, зокрема клопотання, звертання, скарги та інші листи від місцевих мешканців, всякі протоколи громадських зборів.

На території Правобережної та частково Центральної України специфіка формування архівосховищ відбувалась під впливом довготривалого перебування цих українських земель у складі полонської держави - Речі Посполитої.В губернські архіви Правобережжя передавалися справи колишніх воєводських канцелярій, а в казенні палати - вотчинні документи і монастирські грамоти.

Політика зберігання документів у Російській імперії суттєво вплинула 
на розвиток архівної справи Лівобережної Україні XIX ст. Укази, постанови, розпорядження й нормативні акти всіляких відомств і державних установ зачіпали архівне будівництво, тобто збирання документальних напрацювань, розподілення й регламентацію архівних фондів, порядок ліквідації ветхих архівних відомостей, поліпшення умов для зберігання офіційних ділових паперів та формування ретроспективних реєстрів. Згідно $з$ царським указом (1798р.), усі відпрацьовані в нижчестоящих інстанціях документи на місцях здавалися до губернських архівів з розподіленням за відповідними відомствами (спроби галузевої класифікації). Так, закриті судові справи передавалися до архівів судових палат, фінансово-майнові звіти зосереджувалися у губернських казенних палатах, а всіма іншими адміністративними документами комплектувався архів губернського правління.

Міністерство внутрішніх справ видало спеціальний циркуляр, де зазначалося про вимоги впорядкування архівів судових установ, канцелярій прокурорів та стряпчих. Згідно 3 ним, встановлювався щорічний перегляд усіх документів для відбору тих, термін зберігання яких перевищив десять років. 31867 р. губернським посадовцям було дозволено створювати спеціальні комісії для проведення ревізій архівних справ. Задля забезпечення функціонування архівів ліквідованих канцелярій новоросійської і бессарабської губернаторій та виплати грошового утримання архівним службовцям у 1874 р. Урядом було виділено суттєву фінансову підмогу (понад 3000 рублів) [2, с. 26-37].

Численні спроби реформувати архівну справу задля підведення під неї єдиної правової і нормативно-методичної бази мали місце наприкінці XIX - початку XX ст., але щоразу наштовхувалися на опір представників адміністративно-бюрократичного апарату. На жаль, жоден проєкт архівної реформи в цей період не був реалізований [10, с. 190-195].

Значний внесок в оформлення ідеї централізації архівної справи українських земель здійснила Спілка російських архівних діячів, яка була створена й очолена академіком А. Лаппо-Данилевським у березні 1917 р. Саме цей альянс приступив до підготовки докорінної реформи, кінцевою метою якої було створення вельми авторитетного органу щодо керівництва архівною справою на загальнодержавному рівні. Першою спробою розроблення закону про архіви став проєкт кандидата в члени ради Союзу російських архівних діячів начальника архіву і бібліотеки Священного Синоду К. Здравомислова. Назва проєкту «Про долю архівів скасованих установ і відомств» говорила саме за себе. В ньому висловлювалося занепокоєння за збереження ліквідованих у результаті Лютневої революції архівних установ та декларувалась їх незахищеність. Проєкт закону К. Здравомислова за змістом і формою був докладною запискою, в якій узагальнювались ідеї та ставилось питання державного масштабу про те, що треба робити з архівами скасованих Тимчасовим урядом установ і відомств.

Цей проєкт не отримав практичного втілення. Одночасно зі створенням Союзу російських архівних діячів в Росії був розроблений ще один законопроєкт архівної реформи, автором якого був Ф. Ніневія.

18 березня 1917 р. Ф. Ніневія направив Тимчасовому уряду «Записку про організацію архівів в Росії. Одночасно він звернувся 3 пропозицією про проведення загального архівного перетворення. У записці і в листі до Думи автор проєкту вказував на невпорядкований стан архівів, хоча «архівні питання, на його думку, національне питання, і не останньої важливості» $[15$, с. 9-16].

Говорячи про основні напрями планованої реформи, Ф. Ніневія 
спробував пов'язати питання централізації архівів Морського міністерства і Військового відомства з фінансовими питаннями, зазначивши, що витрати на архіви при цьому не збільшяться, а зменшяться. Наприклад, концентрація архівів в одному центральному архіві Військового міністерства (а їх тільки в Петрограді було більше 20, не рахуючи полкових архівів) привела б до скорочення чисельності штатів, отже, до значної економії коштів. Ф. Ніневія вважав, що цей підхід необхідно поширити не тільки на військове, але й на інші міністерства. Таким чином, його проєкт фактично виходив за відомчі межі. Документи невійськових відомств і установ він пропонував зосереджувати не тільки в загальних архівах міністерств, але й на місцях, в окружних архівах.

Почати ж реформу $\Phi$. Ніневія пропонував з архіву Державної Думи і висловлював готовність особисто взятися за цю справу. Ф. Ніневія пропонував запозичити французький досвід використання після революціі кінця XVIII ст. вільних палацових приміщень під архіви та музеї і поділу країни на провінційні архівні округи. До витрат на архіви в провінціі він вважав за необхідне залучити органи місцевого самоврядування та інші державні установи.

Знаючи інерцію і консерватизм бюрократичного апарату російської держави, Ф. Ніневія під час просування свого проєкту до статусу закону розраховував обійтися без комісій. Створити ж іï він пропонував лише «за остаточного розгляду і схвалення проєкту, куди б увійшли досвідчені, практично підготовлені особи з істориків, юристів і будівельників-архітекторів».

3 іншого боку, проєкт реформи повинен базуватися на офіційних даних, збір яких був «недоступний для приватної особи» і можливий лише за допомогою вищих державних установ. Лист і брошура були послані професору, міністру Тимчасового уряду П. Мілюкову в березні 1917 р., однак Ф. Ніневія не отримав жодної відповіді на свої пропозиції.

Окремо зазначимо, що архіви царської «Охранки», що належали охоронному відділенню МВС Російської імперії, були повністю знищені пожежею. Це сталося після Лютневої революції 1917 р. і падіння монархії.

Таким чином, проаналізувавши правові акти Російської імперії, а також проєкти законів про централізацію архівної справи, маємо відзначити, що царський уряд не виробив єдиної політики щодо реорганізації архівної справи, хоча реформатори XIX ст. створили для цього міцну базу. Наукова інтелігенція піднімала проблему збереження національного надбання, а саме архівів.

Основними ідеями всіх відомих проєктів реорганізації архівної справи Російської імперії були концентрація історичних документів, неподільність фондів і централізація системи управління архівними установами. Однак жоден з відомих проєктів не отримав практичного втілення. До революціі в Російський імперії нараховувалось понад 120 тис. урядових і громадських архівів. Кожен з них підпорядковувався відповідному відомству, але вся мережа архівних установ не мала єдиного координуючого органу. Офіційні документи передавалися 3 канцелярії в поточні архіви, а звідти у відомчі архіви, де затримувались на десятки років. Щодо приватних архівів, то вони залишалися без урядового контролю, а їх загибель мала всеосяжний характер.

Діяльність створених на місцях учених архівних комісій можна охарактеризувати як спробу наукової громадськості зберегти архівну спадщину, однак низка причин перешкоджала цьому: по-перше, відсутність закону про архіви та відсутність підтримки царського уряду в рішенні цього питання; по-друге, складність політичної та фінансової обстановки.

Однак, незважаючи на очевидні провали проєктів реформування 
архівної справи, саме в кінці XIX на початку XX ст. остаточно сформувалась науково-теоретична база для законодавчого закріплення положень про архівну справу.

У 1918 р. архіви були націоналізовані, а очолювало вертикаль управління у цій сфері Головне управління архівною справою [1, с. 24-32]. З 1922 р. усі державні архівні установи та архівні підрозділи країни підпорядковувалися Центрархіву РРФСР. У 1930-ті рр. в СРСР сформувалася тоталітарна модель організації архівної справи, основні риси якої дожили практично до кінця 1980-х початку 1990-х рр.

На новітньому етапі відновлення української державності відбувалось оновлення нормативно-правової бази про архіви та архівну справу. Цей процес продовжується в нових інноваційних умовах цифровізації та глобалізації архівно-інформаційного простору, зокрема вкорінюється онлайн-ознайомлення зі справами в читальних залах, модернізується система зберігання аудіовізуальних документів у цифрових комунікаціях [13]. У 2020 р. затверджено «Стратегії розвитку архівної справи на період до 2025 року».

Висновки. Проведений історико-правовий аналіз дає змогу визначити основні етапи розвитку архівного законодавства. Перший етап (з IX до кінця XV ст. ст.) включає появу розрізнених архівів, що не являли собою єдину систему, адже книги, літописи, документи зберігалися разом з матеріальними цінностями і не виділялися в окремий фонд. Другий етап (кінець XV - початок XVIII ст. ст.) характеризується появою перших державних установ, а водночас і бюрократичного апарату, що зробило позитивний вплив на формування архівної справу, вперше з'явились окремі архівні фонди. На західно-українських землях формування принципів регулювання архівної справи відбувалося під впливом традицій магдебурзького права, а у східній частині нашої держави домінувало російське право. На третьому етапі (початок XVIII ст. 1917 р.) з'явилися перші історичні архіви, зросла потреба в систематизації інформації, архіви перетворились на автономні структурні установи. Юридично відділення архівів від канцелярій було закріплено в Генеральному регламенті (1720р.). Четвертий етап (1917-1991рр.) характеризувався тим, що жорстка централізація влади поширювалась на централізацію законодавства. П'ятий етап триває з 1991 p.

У статті розкрито основні еволюиійні етапи нормативного регулювання відносин в архівній галузі на ранніх етапах розвитку суспільства та простежено, як змінювалось законодавство про архіви та архівну справу в дорадянську добу. 3'ясовано історико-правові засади організаціі та функціонування архівної діяльності. Визначено n'ять основних етапів розвитку архівного законодавства. Зроблено висновки, щз у період з кіния $X V$ до початку XVIII cm. cm. на західноукраїнських землях формування принципів регулювання архівної справи відбувалося піо впливом традииій магдебурзького права, а у східній частині нашої держави домінувало російське право. Це доводить той факт, що архівна справа тісно пов'язана з розвитком державності. Встановлено, що, незважаючи на очевидні провали проєктів реформування архівної справи, саме в кінці XIX cm. - на початку $X X \mathrm{~cm}$. остаточно сформувалась науково-теоретична база для законодавчого закріплення положень про архівну справу. За часів колишнього СРСР у 1930-ті рр. було сформовано тоталітарну модель організації архівної справи, основні риси якої дожили практично до кіния 1980-х - початку 1990-х рр. Підкреслено, що хоча знання про 
архівне право зародилися дуже давно, проте архівне законодавство ще не є самостійною галуззю правової системи України, а є комплексною системою законодавства, що формується у вигляді сукупності джерел, що включають норми різних галузей права. Проведений історико-правовий аналіз дав змогу визначити такі основні етапи розвитку архівного законодавства: перший (з IX до кінияя XV cm. cm.), другий (кінець XV-початок XVIII cm.cm.), mретій (початокXVIIIcm.-1917p.), четвертий (1917-1991 рр.), п’ятий (триває з 1991 р.). На новітньому етапі відновлення української державності відбувалось оновлення нормативно-правової бази про архіви та архівну справу. Цей процеес продовжуеться в нових інноваиійних умовах ичифровізаціі та глобалізаціі архівно-інформаційного простору, зокрема вкорінюеться онлайн-ознайомлення зі справами в читальних залах, модернізується система зберігання аудіовізуальних документів у цифрових комунікацуіях.

Ключові слова: архівне право, архівне законодавство, Генеральний регламент, єдиний державний архівний фонд, документи, правила роботи державних архівів.

Horishnia M. Genesis of regulatory regulation legal relations in the archival sphere

The article reveals the main evolutionary stages of normative regulation of relations in the archival field in the early stages of society and traces how the legislation on archives and archival affairs changed in the pre-Soviet era. The historical and legal principles of organization and functioning of archival activity are clarified. There are five main stages in the development of archival legislation. It is concluded that in the period from the end of the $X V$ to the beginning of the XVIII century. In the western Ukrainian lands the formation of the principles of regulation of archival affairs took place under the influence of the traditions of Magdeburg law, and in the eastern part of our state Russian law dominated. This proves the fact that archival affairs are closely connected with the development of statehood. It is established that despite the obvious failures of archival reform projects, it was at the end of the XIX century early XX century. The scientific and theoretical basis for legislative consolidation of provisions on archival business was finally formed. During the former Soviet Union, a totalitarian model of archival organization was formed in the 1930s, the main features of which lasted almost until the late 1980s and early 1990s is not yet an independent branch of the legal system of Ukraine - it is a complex system of legislation, which is formed in the form of a set of sources that include the rules of various branches of law. The conducted historical and legal analysis made it possible to determine the main stages of development of archival legislation: the first (from $I X$ to the end of $X V$ century), the second (end of $X V$ - beginning of XVIII century), the third (beginning of XVIII century - 1917), the fourth (1917-1991), the fifth, which has lasted since 1991. At the latest stage of restoration of Ukrainian statehood there was an update of the legal framework on archives and archival affairs. This process continues in the new innovative conditions of digitalization and globalization of the archival and information space, in particular, online acquaintance with cases in reading rooms is being introduced, the system of storing audiovisual documents in digital communications is being modernized.

Key words: archival law, archival legislation, general regulations, unified state archival fund, documents, rules of work of state archives. 


\section{Література}

1. Акимов С. Последние шаги к архивной реформе 1918 г. (Проекть E. Квашнина-Самарина, А. Лебедева, К. Здравомыслова, Н. Голищына, Ф. Ниневе). Отечественные архивы. 2001. № 5. C. 24-32.

2. Архівознавство : підручник для студентів вищих навчальних закладів України / редкол.: Я. Калакура (гол. ред.) ma ін. Київ, 1998. 316 c.

3. Бржостовская Н. Архивы и архивное дело в зарубежных странах (История и современная организация) : учебное пособие / под. ред. Ю. Кононова. Москва: МГИАИ, 1972. $311 \mathrm{c}$.

4. Вовкотруб О., Фионова Л. Архивоведение : учебное пособие. Пенза : ПГУ, 2005. 132 c.

5. Гагиева А. Становление и формирование архивного дела в России (IX в. начало XX вв.) : учебное пособие : в 2 и. Сыктыькар : КРАГСиУ, 2007. Ч. 1-2.

6. Емышева Е. Генеральный регламент - начало законодательного регулирования системы организации управления и делопроизводства. Делопроизводство. 2003. № 1. C. 103-110.

7. Ларин М. Государственное регулирование делопроизводства в России: история и современность. Делопроизводство. 2002. № 1. С. 3-8.

8. Медведева О. Правовая и нормативно-правовая база архивного дела в России. Соииально-экономические явления и процессы. 2014. № 1. С. 143-147.

9. Медведева O., Сенина Е. Развитие архивного дела в российской провиниии до ХХ в. Известия Томского политех- нического университета. 2012. Т. 320. № 6. C. 158-161.

10. Медведева О., Сенина Е. Формирование архивного законодательства в России. Социально-экономические явления и проиессы. 2012. № 9. С. 190-195.

11. Самоквасов Д. Архивное дело в России. Кн. 1-2. Москва, 1902. 550 с.

12. Самоменко В. Архивное дело в период построения соииализма в СССР. 1917-1937 : учебное пособие. Москва, 1982. $76 \mathrm{C}$.

13. Синеокий О. Гибридизащия как инструмент модернизации системы хранения фонодокументов в иифровом коммуникационном пространстве (на примерах фонохранилищ, Украинь, Белоруссии, России, Азербайджана). Частное и общественное в повседневной жизни населения России: история и современность : материаль международной научной конференциии. Санкт-Петербург, 2018. С. 121-128.

14. Энииклопедический словарь под ред. И. Андреевского, К. Арсеньева, Ф. Петрушевского ; изд. Ф. Брокгауз [Лейпциц], И. Ефрон /Санкт-Петербирга. Санкт-Петербирг : Семеновская Типо-Литография И. Ефрона, 1890-1907. T. 1-41A [1-82], don. 1-2A [1-4].

15. Химина H. Отечественное архивное строительство: идея иентрализации на рубеже XIX - XX вв. Отечественные архивы. 1998. № 4. С. 9-16.

16. Хорхордина T., Волкова T. Российске архивы: история и современность : учебник для вузов / отв. ред. В. Минаев. Москва: Издательский иентр РГГУ, 2012. 414 C 